\title{
Impact of Demographical Factors on Work Life Balance among Academic Staff of University of Kelaniya, Sri Lanka
}

\author{
M.K.D. Padmasiri, W.G.S. Mahalekamge \\ University of Kelaniya, Sri Lanka \\ dinithipadmasiri@kln.ac.lk
}

\begin{abstract}
The focus of this research is to find out the impact of demographical factors on Work Life Balance among academic staff of University of Kelaniya. Objective is examining the impact of selected demographical factors; gender, marital status and investigate best and worst gender level and marital status of Work Life Balance. Research sample consists with 150 lecturers out of 560 lecturers in University of Kelaniya. Based on random sampling method standardized questionnaires are distributed to collect data. Based on the analysis researchers identified that there is significant relationships among gender, and marital status and Work Life Balance excluding age as a demographic factor. Further identified females as a best group in Work Life Balance and under marital status single group is having Work life Balance greater than married group. Based on findings researchers established that there is a significant impact of gender and marital status on Work Life Balance as demographic factors.
\end{abstract}

Keywords: Demographic, Gender, Marital Status, Age, Work Life Balance, Academic

\section{Introduction}

In any context Human Resource Management (HRM) is an about the effective and efficient utilization of workforce in order to achieve an organizations' goals and objectives. The generic purpose of HRM is to select and retain the most appropriate work force within the organization. Human resourcing is the key to determining organizational success. Balancing work - family is a vital factor to the employee for their personal and career development. Improving quality of WLB helps to improve the productivity, increasing employee loyalty and job satisfaction. There had been done lot of research by many researches to investigate work, family and personal life during the last few decades. As a result, studies have examined the term "WLB" which means the proper balance between career and personal life. Work-life balance is creating healthy work environment and strengthen the employee loyalty and productivity. Work-life conflict is highly impact to employee performance as well as organization performance and employees' physical and mental health implications. Therefore in today most of the organization helps to balance work and personal life of the employees.

Demographic factors of the employees are impact to the work life balance of the employees. According to Bird (2006) balancing work and family life is often more difficult for women than for men because women have more family responsibilities. It indicates gender becomes a significant factor in WLB. And also marital status has the biggest impact on working hours. Single men and women are least likely to work long hours (Eikhof, 2007). Hence as another demographic factor marital status becomes significant variable in WLB. According to Torrington et al. (2008) cited in; the ageing workforce, a tight labor market, caring responsibilities, work-life conflict, long working hours, work intensification and greater levels of stress form part of demands of life. It can be concluded that age plays a significant role in WLB. Therefore a healthy practice of WLB is changed based on the demographical factors such as gender, marital status, and age. This study focused on the impact of demographical factors on Work Life Balance (WLB) of the academic staff of the University of Kelaniya as a state university in Sri Lanka. WL of academic staff rather different from the other careers due to special characteristics relate to this field such as knowledge base work, high work load. According to Harry-Rutter (2002) identified several characteristics among the academic staff such as high self-expectation, role overload, conflicting job demands. Therefore the current study focuses on the testing the relationship of demographical factors on WLB of academic staff in University of Kelaniya (Eikhof, 2007). 
Research Problem: According to Devadoss (2013) Work Life imbalance is result to increase the problems related to employee at work place, decrease the productivity and efficiency and cause to increase social hazards such as increasing number of divorces, increase stress levels etc. Bolhari et al (2011) studied the relationship between income, age, gender and work experience. According to that there was no significant relationship between gender and quality of work life, but identified the relationships between quality of work life and age, work experience and income. According to Fisher and Layte (2003), they identified three important factors which impact to WLB such as free time, the activities related to work and other dimensions of life and the time spent with other people. And also the variables such as the gender, age, citizenship, ethnicity and life cycle stage have significant impact on WLB of Employees (Wallance and Cousins, 2004). Consequently, identified problem is "How demographical differences of academic staff impact on their WLB?"

Research Objectives: General objective of this research is to examine the impact of selected demographical factors of academic staff in University of Kelaniya on their WLB. On that general objective Specific objectives are established as follows.

- To identify the impact of gender on WLB of academic staff.

- To identify the impact of marital status on WLB of academic staff

- To identify the impact of age on WLB of academic staff

- To identify best and worst gender, marital status on WLB of academic staff.

\section{Literature Review}

WLB: WLB is defined as a satisfactory level of involvement or fit between the different roles in a person's life and career life (Hudson, 2005). According to (Clark, 2003), WLB refers that there is minimum role conflicts between work and personal life. In the words of (Blatt, 2002) WLB is an absence of unacceptable levels of conflict between work and personal life. (Haché, 2002) described WLB is a inter relationship among different life roles. It is an inter relationship among different life aspects such as social, physical, intellectual, emotional, spiritual, and work. Sub dimensions of WLB are, work, family, self and social. It developed according to Dundas (2008) WLB is about effectively managing the work and all other activities that are important to people such as family, community activities, social, personal development and leisure and recreation. Working definition of WLB is a the way of managing time among work, family, self and social activities of a personal life .

Gender on WLB: The relationship between gender and WLB has been examined frequently with conflicting results. Some studies indicate that women have greater WLB than men whereas others report the opposite but most report no significant differences between them. Based on the study of home based Tele workers Sullivan \& Lewis (2001) found that women's experiences of WLB are mediated by parental status and career involvement. According to that women who have young children reporting higher levels of family to work interference and women who have high career involvement experiencing higher levels of interference from work to family. Therefore it can be concluded that there is a significant relationship between demographic variables and WLB of women employees. The relationship between demographic variables and work-life balance of employees and it will helps to design policies for employees to address WLB issues.

Marital Status on WLB: In today's society, managing a stressful job and dedicating quality time to family is definitely becoming a major challenge. Today more women engage in managerial jobs and they want to balance both professional and personal life. More family obligations have the women who are in corporate employment (Parasuraman and Simmers, 2001; Hardy and Adnett, 2002) and also WLB also an issue for working men too. Data indicates that in the families where childcare is shared men are likely to experience similar levels of work-life conflict as women (Duxbury and Higgins, 2008). The study of (Allen, 2001) also indicated that married employees are more likely to use these policies compared to unmarried employees.

Age on WLB: Age is another factor which affecting to WLB of the employee. Allen (2001) suggested that though age differences do not impact the use of WLB practices, the choice of the practice differs with age. Older employees are found to use many dependent care policies like Childcare, Elder care, Paid Maternity leave etc. According to DiNatale \& Boraas (2002) 25 to 34 year old women are more likely than women of other ages search for flexibility in their jobs. This is possibly attributed to the responsibilities associated with 
dependent care in this age group as women need time for the young ones at home. Though Child care facilities are available, women still depend on friends and family rather than paid-help to take care of their kids. This is studied in a research by Susan-Halford (1997) in Banking, Local Government and Nursing Sectors.

\section{Methodology}

Sampling Method: Simple random sampling method is the technique used by the researchers as sampling method to provide equal opportunities to the population being in the sample. Here the sample consists of 150 lecturers from the 560 academic staff of University of Kelaniya.

Method of Data collection: The questionnaire consists 45 close ended questions with two parts; information on demographical factors and WLB. Initial part of the questionnaire investigated information on demographic factors of respondents. Researchers used standard questionnaire to identify the WLB (Minnesota satisfaction questionnaire and Zarca interactive questionnaire). Reliability of the WLB questionnaire is 0.958 (Cronbatche's Alpha Value) therefore WLB questionnaire is supporting to measure that particular variable.

Data analysis: Quantitative method was used to analyze the data. The data analyzed in this study based on the questionnaires. Under the quantitative method, the Likert Scale was included to measure WLB. 5 point Likert- scales were used to score the responses from Strongly Agree to Strongly Disagree.

\section{Findings}

WLB and Gender

Figure 1: Gender Composition of Sample

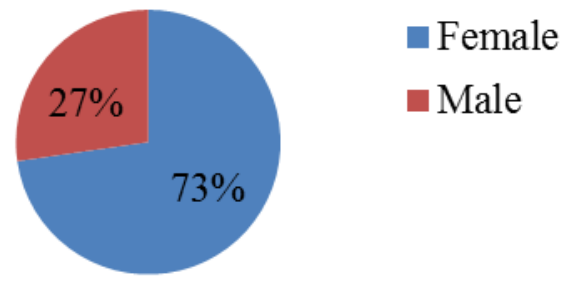

Source: Primary Data

According to the above figure 1 sample consists with 109 females \& 41 males.

\section{Impact of Gender on WLB}

Table 1: WLB and Gender - Group Statistics

\begin{tabular}{llllll}
\hline & Gender & $\mathbf{N}$ & Mean & Std. Deviation & Std. Error Mean \\
\hline \multirow{2}{*}{ Work Life Balance Variable } & Female & 109 & 4.10 & .871 & .083 \\
& Male & 41 & 3.73 & 1.162 & .182 \\
\hline
\end{tabular}

Source: Primary Data 
Table 2: WLB and Gender - Independent Samples Test

\begin{tabular}{|c|c|c|c|c|c|c|c|c|c|c|}
\hline & \multicolumn{9}{|c|}{$\begin{array}{l}\text { Levene's Testt-test for Equality of Means } \\
\text { for Equality of } \\
\text { Variances }\end{array}$} \\
\hline & & $\mathbf{F}$ & Sig. & $\mathbf{t}$ & df & $\begin{array}{l}\text { Sig. } \\
\text { tailed) }\end{array}$ & $\begin{array}{l}\text { (2-Mean } \\
\text { Differer }\end{array}$ & $\begin{array}{l}\text { Std. } \\
\text { ceDiffer }\end{array}$ & $\begin{array}{l}\text { Error } 95 \% \\
\text { rence Interval } \\
\text { Difference }\end{array}$ & $\begin{array}{l}\text { Confidence } \\
\text { of the }\end{array}$ \\
\hline & & & & & & & & & Lower & Upper \\
\hline $\begin{array}{l}\text { Work } \\
\text { Life }\end{array}$ & $\begin{array}{l}\text { Equal variances, } \\
\text { assumed }\end{array}$ & $\mathrm{s}_{12.339}$ & .001 & 2.103 & 148 & .037 & .369 & .176 & .022 & .716 \\
\hline $\begin{array}{l}\text { Balance } \\
\text { Variabl }\end{array}$ & $\begin{array}{l}\text { Equal variances } \\
\text { enot assumed }\end{array}$ & & & 1.848 & 57.716 & .070 & .369 & .200 & -.031 & .769 \\
\hline
\end{tabular}

Source: Primary Data

According to Table 2 Levene's Test for Equality of Variances shows male group and female group have difference in WLB because it findings show 0.001 significant value which is less than 0.05 . It has again proven in Table 3 which shows mean values of females and males respectively 4.10 and 3.73. In Independent sample $\mathrm{t}$ - test for WLB and Gender significant value is 0.037 which is less than 0.05 . It indicates "There is a significant difference between males and females hence; gender is a significant factor affecting WLB. It could be concluded that there is a significant difference in WLB between males and females. Comparing the results of males and females in WLB shows females have WLB than men because mean value of females in WLB is 4.10 which closed to strongly satisfactory level (5). Therefore females identified as best group in gender factor who have ability to manage WL.

\section{WLB and Marital Status}

Table 3: WLB and Marital Status - Group Statistics

\begin{tabular}{llllll}
\hline & Marital Status & N & Mean & Std. Deviation & Std. Error Mean \\
\hline \multirow{2}{*}{ Work Life Balance Variable } & Single & 52 & 4.23 & 1.131 & .157 \\
& Married & 98 & 3.88 & .853 & .086 \\
\hline
\end{tabular}

Source: Primary Data

Table 4: WLB and Marital Status- Independent Samples Test Levene's Test t-test for Equality of Means for Equality of Variances

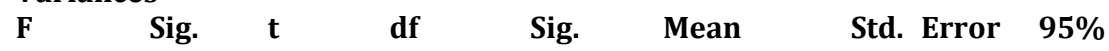
(2- Difference Difference Confidence tailed) Interval of the Difference

\begin{tabular}{|c|c|c|c|c|c|c|c|c|c|c|}
\hline & & & & & & & & & Differ & \\
\hline & & & & & & & & & Lower & Upper \\
\hline Work Life & Equal & 7.780 & .006 & 2.150 & 148 & .033 & .353 & .164 & .029 & .678 \\
\hline $\begin{array}{l}\text { Balance } \\
\text { Variable }\end{array}$ & variances & & & & & & & & & \\
\hline Variable & assumed & & & & & & & & & \\
\hline & & & & 1.974 & 82.464 & .052 & .353 & .179 & -.003 & .709 \\
\hline & & & & & & & & & & \\
\hline & assumed & & & & & & & & & \\
\hline
\end{tabular}

Source: Primary Data

According to table 4 Levene's Test for Equality of Variances shows single group and married group have difference in WLB because it findings show 0.006 significant value which is less than 0.05 . Meanwhile table 3 shows mean values of single and married respectively 4.23 and 3.88. In Independent sample $t$ - test for WLB and Marital state significant value is 0.033 which is less than 0.05 . It indicates "There is a significant difference between single and married groups", therefore marital state is a significant factor affecting WLB. It could be concluded that there is a significant difference in WLB between single and married groups. And in 
mean comparison of single and married groups in WLB shows single group has WLB comparing to other group because mean value of single group in WLB is 4.23 and married group is 3.88.Single group closed to strongly satisfactory level (5) therefore that group identified as the best group in marital status factor who have ability to manage WL.

\section{WLB and Age}

Table 5: WLB and Age - ANOVA

Work Life Balance Variable

\begin{tabular}{llllll}
\hline & \multicolumn{1}{l}{ Sum of Squares df } & Mean Square & F & Sig. \\
\hline Between Groups & .315 & 3 & .105 & .110 & .954 \\
Within Groups & 139.685 & 146 & .957 & & \\
Total & 140.000 & 149 & & & \\
\hline
\end{tabular}

Source: Primary Data

Table 6: WLB and Age -Multiple Comparisons

Dependent Variable: Work Life Balance Variable

Tukey HSD

\begin{tabular}{lllllll}
\hline (I) Age & (J) Age & $\begin{array}{l}\text { Mean } \\
\text { Difference (I-J) }\end{array}$ & Std. Error & Sig. & \multicolumn{2}{l}{$\begin{array}{l}\text { 95\% Confidence Interval } \\
\text { Lower Bound }\end{array}$} \\
& & & & .600 \\
$20-24$ & $25-29$ & .015 & .224 & 1.000 & -.57 & .60 \\
& $30-34$ & .131 & .286 & .968 & -.61 & .87 \\
& $35-39$ & .083 & .283 & .991 & -.65 & .82 \\
$25-29$ & $20-24$ & -.015 & .224 & 1.000 & -.60 & .57 \\
& $30-34$ & .116 & .235 & .961 & -.50 & .73 \\
& $35-39$ & .068 & .231 & .991 & -.53 & .67 \\
$30-34$ & $20-24$ & -.131 & .286 & .968 & -.87 & .61 \\
& $25-29$ & -.116 & .235 & .961 & -.73 & .50 \\
& $35-39$ & -.047 & .292 & .998 & -.81 & .71 \\
$35-39$ & $20-24$ & -.083 & .283 & .991 & -.82 & .65 \\
& $25-29$ & -.068 & .231 & .991 & -.67 & .53 \\
& $30-34$ & .047 & .292 & .998 & -.71 & .81 \\
\hline
\end{tabular}

Source: Primary Data

According to the ANOVA results age is not a significant factor in WLB hence its value is 0.954 . To be a significant factor value should be less than 0.05. Multiple Comparison also proved that previous finding which shows mean value of one age level comparing to another age level's mean value also greater than 0.05 . It indicates WLB is not change due to age factor. It can be concluded that age is not a significant factor affecting WLB.

\section{Conclusion}

The current study focuses on the testing the impact of demographic factors on WLB of academic staff of University of Kelaniya. General objective was, examine the impact of selected demographical factors on WLB with specific objectives such as to identify the impact of gender, marital status and age on WLB of academic staff in University of Kelaniya. And researchers investigated best and worst gender level, marital status and age of WLB of selected sample respondents. In this study researchers faced few limitations such as lack of literature in the Sri Lankan context regarding this research problem and there is no data with regard to the WLB in the Sri Lankan academic sector. According to the findings gender is a significant factor affecting WLB and male group and female group have difference in WLB where females identified as the best group in WLB comparing to men. And also analysis showed single group and married group have difference in WLB by indicating single group as the best group in WLB. Finally ANOVA results showed of age is not a significant factor affecting WLB. Final findings of this study achieved established research objectives successfully. 
Recommendations: Implement 'Flex works' concept providing more stretchy roistering schedules and works to staff as the best practice to WLB. Additionally sensible work hours practice which reducing excessively long working hours also contributes to WLB. Improving safety and well-being in the workplace is essential to WLB. Providing telephone facilities will ensure all employees are able to receive and get communication facility with family members at work and it will suppose to balance both family and work life. Another recommendation is initiating welfare facilities including cafeteria, gym, and entertainment places to be relaxed at the workplace. Arranging staff transport services is also helpful for reducing time spent on commuting. It helps to save time to balance juggling demands effective way. And also develop WLB policies that assist staff to achieve a WLB. Those policies should supported by the organization culture (beliefs, values and norms) and management support is critical. Further, healthiness of employees and recommend for creating a vitalizing work experience and environment. Above suggestions will support enhance employee mental satisfaction and it will lead enhance strength to balance their WL. Not only that for WLB people ability to manage them-selves also needed to be enhance.

\section{References}

Allen. (2001). Family-Supportive Work environments: the role of organizational perceptions. Journal of Vocational Behavior, 58(3) 414-435.

Bird, S. R. (2006). Theorizing masculinities: recent trends in the social sciences, Gender Studies.

Bolhari, A., Rezaeen, A., Bolhari, J. \& Bairamzadeh, S. (2011). The relationship between quality of work life and demographic characteristics of information technology staff.

Blatt, G. (2002). Work/ Life balance; Wisdom or Whining. Organizational Dynamics, 31(2), 177 - 233.

Clark, E. A. (2003). Behavioural and Cognitive Psychotherapy (Vol. 31).

Devadoss A. V. J. M. (2013). A Study of Personality Influence in Building Work Life Balance Using Fuzzy Relation Mapping (FRM). A Study of Personality Influence in Building Work Life Balance Using Fuzzy Relation Mapping (FRM). The International Journal of Data Mining Techniques and Applications (IJDMTA) , 02, 211-216.

DiNatale, M. \& Boraas, S. (2002). The labor force experience of women from generation X. Monthly Labor Review, 125(3), 3-15.

Duxbury, L. \& Higgins, C. (2008). Work-Life balance in Australia in the new millennium: Rhetoric versus reality. Retrieved from http://www.beatonglobal.com/pdfs/Work-life_balance_full_report.pdf.

Eikhof, C. W. (2007). Introductino:What work? What Life?What balance Critical Reflections on the work life balance debate. Employee Relation, Pg 352-33.

Dundas, K. (2008). Work-Life Balance: There is no 'one-size-fits-all' solution, in K O'Rourke (ed.), Managing Matters. Graduate College of Management, Southern Cross University. New South Wales, 3, 7-8.

Haché, L. D. R. (2002). Memramcook, NB: national Life/Work Centre .

Hardy, S. \& Adnett, N. (2002). The parental directive: towards a 'family-friend' social Europe? European journal of industrial relations, 8, 72-157

Harry-Rutter, J. H. (2002). Stress in doctors and dentists who teach. Medical Education , pg 543-549.

Hudson. (2005). The Case for Work/Life Balance: Closing the Gap Between Policy and Practice.

Fisher, K. \& Layte, M. (2003), Measuring work life balance and degrees of sociability

Parasuraman, S. \& Simmers, C. A. (2001). Type of employment, work-family conflict and well-being: a comparative study. Journal of organizational behavior, 22, 551-68

Sullivan, C. \& Lewis, S. (2001). Home-based Telework, Gender, and the Synchronization of Work and Family: Perspectives of Teleworkers and their Co-residents. Gender Work \& Org, 8(2), 123-145.

Susan-Hafold, M. S. (1997). Gender, Careers and Organisations:Current Developments in Banking, Nursing and Local Government.

Torrington, D., Hall, L. \& Taylor, S. (2008). Human Resource Management, Seventh Edition, FT Prentice Hall, London, p 259.

Wallance, C. \& Cousins, C., (2004), Households, work and flexibility, Http://www.hws.at/downloads/open_area/publications/forum_publications_04.pdf. 